\title{
Volatile profile of the headspace fraction of "assa-peixe" (Vernonia sp.) honeys
}

\author{
Perfil dos compostos voláteis presentes na fração "headspace" de méis de assa-peixe
}

\author{
Mariana Carvalho RIBEIROํㅗ , Ricardo Felipe Alves MOREIRA ${ }^{1}$, Carlos Alberto Bastos DE MARIA ${ }^{1 *}$
}

\begin{abstract}
The volatile compounds were isolated from the headspace fraction of "assa-peixe" honeys by adsorptive column chromatography, eluted with acetone and analysed by GC-FID and GC-MS. Volatile compounds were separated using a polar phase column. Low- and mediumboiling-point volatile compounds predominated in the headspace. A large proportion of 3-penten-2-one $\left(80.5 \pm 13.9 \mu \mathrm{g} . \mathrm{kg}^{-1}\right)$ and benzaldehyde $\left(25.9 \pm 4.2 \mu \mathrm{g} . \mathrm{kg}^{-1}\right)$ was found in the headspace fraction, while 2-penten-1-ol, 3-hexenyl butanoate, octadecane and hexanoic acid $\left(<0.01 \mu \mathrm{g} . \mathrm{kg}^{-1}\right)$ were by far the less abundant volatile compounds. A total of 12 volatile compounds were identified and, among them, 5 compounds were reported as "assa-peixe" honey constituents for the first time. Of the 5 new volatile compounds reported, 3-penten-2-one, dodecane, tridecane and benzaldehyde were definitively identified in the headspace fraction of Brazilian "assa-peixe" honeys.

Keywords: GC-MS; headspace; aroma; "assa-peixe" honey.
\end{abstract}

\section{Resumo}

Os compostos voláteis da fração "Headspace" de méis de assa-peixe foram adsorvidos pela técnica de cromatografia de adsorção, eluídos com acetona e analisados através da CG/DIC e CG/EM usando coluna polar de sílica fundida. Os compostos voláteis de baixo e médio ponto de ebulição predominaram na fração "headspace". Foi achada uma grande proporção de 3-penten-2-ona $(80,5 \pm 13,9 \mu \mathrm{g}$.kg-1) e benzaldeído (25,9 $\left.\pm 4,2 \mu \mathrm{g} \cdot \mathrm{kg}^{-1}\right)$, enquanto o 2-penten-1-ol, o hexanoato de 3-hexenila, o octadecano e o ácido hexanóico $\left(<0,01 \mu \mathrm{g} \cdot \mathrm{kg}^{-1}\right)$ foram compostos minoritários. Um total de doze compostos voláteis foi identificado, sendo cinco descritos pela primeira vez no mel de assa-peixe. Destes cinco, a 3-penten-2-ona, o dodecano, o tridecano e o benzaldeído foram definitivamente identificados na fração "headspace" dos méis de assa-peixe brasileiro.

Palavras-chave: CG/EM, "headspace", aroma, mel de assa-peixe.

\section{Introduction}

Brazil has a vast number of unifloral honeys with exotic aromas and flavours that are greatly appreciated by consumers. The typical Brazilian "assa-peixe" honey is mainly produced in the south-eastern region of Brazil. This unifloral honey has a dark brown colour and characteristic flavour. Information related to the aroma composition of this honey is limited. Recently, however, we reported a study on the identification of volatiles from aqueous "assa-peixe" honey solutions (MATOS et al., 2002). In this case, these solutions were directly passed through an adsorptive Porapak trap, eluted with acetone and analysed by gas chromatography (GC) combined with flame ionization detection (FID) and mass spectrometry (MS). A total of 31 compounds were identified in the aqueous extract of the "assa-peixe" honey. Alcohols, hydrocarbons, acids, esters and aromatic compounds were the most abundant chemical classes of this aroma concentrate (MATOS et al., 2002).

To date, however, studies of "assa-peixe" honey volatile compounds based on the headspace sampling technique have not been reported. In the present study, we have analysed the volatile composition of an "assa-peixe" headspace fraction by both GC-FID and GC-MS.

\section{Materials and methods}

\subsection{Samples}

Ten authentic "assa-peixe" (Vernonia sp.) honey samples were obtained from Brazilian apicultors. The samples were stored in $250 \mathrm{~mL}$ plastic (low-density polyethylene) bottles at $-18{ }^{\circ} \mathrm{C}$, under $\mathrm{N}_{2}$ atmosphere. Before analysis, the honeys were defrosted at $40{ }^{\circ} \mathrm{C}$ and homogenized by gently stirring for 10 minutes. Screening for floral purity was based on pollen analysis (LOUVEAUX; MAURIZIO; WORWOHL, 1978).

\subsection{Reagents}

Acetone was from Merck (Darmstadt, Germany). All other reagents were supplied by Aldrich (Wisconsin, USA).

\subsection{Isolation of the volatile fraction (MOREIRA; DE MARIA, 2005)}

One hundred millilitres of honey aqueous solution $\left(20 \mathrm{~g} \%\right.$, w. $\left.\mathrm{v}^{-1}\right)$ were placed in a $500 \mathrm{~mL}$ heavy-walled Pyrex filtering flask with a side hose-connection (Brand, Wertheim,

Recebido para publicação em 8/11/2006

Aceito para publicação em 8/6/2007 (002041)

${ }^{1}$ Laboratório de Química de Alimentos - LQA, Instituto Biomédico, Universidade Federal do Estado do Rio de Janeiro - UNIRIO, Rua Frei Caneca, 94, $4^{\circ}$ andar,

Cidade Nova, CEP 20211-040, Rio de Janeiro - RJ, Brasil, E-mail: carreb@uol.com.br

${ }^{*}$ A quem a correspondência deve ser enviada 
Germany), o.d. $10 \mathrm{~mm}$, at $30{ }^{\circ} \mathrm{C}$, under stirring. Purified nitrogen $(0.9-1.0 \mathrm{~L} / \mathrm{min})$ was passed through the system during 3 hours and the entrained volatiles were adsorbed on a glass column $(0.5 \mathrm{~cm}$ i.d. $\times 18 \mathrm{~cm})$ packed with a Porapak Q adsorbent (50-80 mesh) supplied by Supelco (Philadelphia, USA). The polymer was previously conditioned at $225^{\circ} \mathrm{C}$ for 3 hours under $\mathrm{N}_{2}$ at a flow rate of $0.9-1.0 \mathrm{~L} / \mathrm{min}$. The volatiles were subsequently desorbed with acetone $(100 \mathrm{~mL})$ and concentrated to $200 \mu \mathrm{L}$.

\subsection{GC analysis}

GC/FID: A Carlo Erba (Milan, Italy) 5890 GC equipped with a $50 \mathrm{~m} \times 0.25 \mathrm{~mm}$ i.d. LM-120 polar polyethylene glycol capillary column $\left(\mathrm{d}_{\mathrm{f}}=0.50 \mu \mathrm{m}, \mathrm{L} \& \mathrm{M}\right.$, São Paulo, Brazil $)$ and a FID were employed. The injector and detector temperatures were 230 and $240{ }^{\circ} \mathrm{C}$. Helium was used as the carrier gas at a $0.83 \mathrm{~mL} / \mathrm{min}$ flow rate. The oven temperature was programmed from 50 to $230^{\circ} \mathrm{C}$ at $3{ }^{\circ} \mathrm{C} / \mathrm{min}$. The split ratio was $1: 20$. Linear retention indices (LRI) were estimated by using the modified Kövatz method (VAN DEN DOOL; KRATZ, 1963). All honey samples were analysed in two replicates. The estimated composition of the volatiles was carried out by external standardization and means and standard deviations were obtained for all the volatiles quantified.

GC/MS: A Shimadzu (Kyoto, Japan) GC-17A/QP5050 quadrupole mass spectrometer was used. The instrument was operated in the electron ionisation mode at $70 \mathrm{eV}$, an ion source temperature of $240^{\circ} \mathrm{C}$ and a mass range of 20 to 300 . Tentative identification of the volatiles was based on the comparison of mass spectra of unknown compounds against the NIST library data of the GC-MS. Where possible, the results were confirmed by comparison with authentic substances.

\section{Results and discussion}

The enrichment of the headspace fraction from the honey aqueous solution samples in the Porapak trap followed by desorption with acetone provided extracts with a slight aroma, but similar to those from the original sample. "Assa-peixe" honey volatile compounds isolated from the headspace are listed in Table 1.

Table 1. Volatile compounds in "assa-peixe" honey.

\begin{tabular}{|c|c|c|}
\hline Compounds & LRI & Concentration $\left(\mu \mathrm{g} \cdot \mathrm{kg}^{-1}, \operatorname{avg} \pm \mathrm{SD}\right)$ \\
\hline 3-penten-2-one $e^{\mathrm{a}, \mathrm{b}}$ & - & $80.5 \pm 13.9$ \\
\hline Dodecane $e^{\mathrm{a}, \mathrm{b}}$ & 1209 & $0.9 \pm 0.5$ \\
\hline 2-penten-1-ol ${ }^{\mathrm{a}, \mathrm{c}}$ & 1281 & $<0.01$ \\
\hline Tridecane $e^{\mathrm{a}, \mathrm{b}}$ & 1303 & $0.9 \pm 0.3$ \\
\hline Tetradecane $^{\mathrm{b}}$ & 1410 & $0.6 \pm 0.2$ \\
\hline 2-ethyl-1-hexanol ${ }^{\mathrm{b}}$ & 1499 & $0.7 \pm 0.3$ \\
\hline Pentadecane ${ }^{\mathrm{b}}$ & 1505 & $0.06 \pm 0.02$ \\
\hline Benzaldehyde ${ }^{\mathrm{a}, \mathrm{b}}$ & 1524 & $25.9 \pm 4.2$ \\
\hline Hexadecane $^{\mathrm{b}}$ & 1608 & $0.04 \pm 0.02$ \\
\hline 3-hexenyl butanoate ${ }^{c}$ & 1658 & $<0.01$ \\
\hline Octadecane $^{\mathrm{b}}$ & 1811 & $<0.01$ \\
\hline Hexanoic acid ${ }^{\mathrm{b}}$ & 1838 & $<0.01$ \\
\hline
\end{tabular}

As expected, low- and medium-boiling-point volatile compounds predominated in the headspace fraction. Although external standardizations were used, no recovery method or GC standardization corrections were applied, and thus, the values presented are estimated values. A total of 12 volatiles were identified and, among them, 5 compounds were reported as "assapeixe" honey constituents for the first time. A large proportion of 3-penten-2-one $\left(80.5 \pm 13.9 \mu \mathrm{g} \cdot \mathrm{kg}^{-1}\right)$ and benzaldehyde $\left(25.9 \pm 4.2 \mu \mathrm{g} . \mathrm{kg}^{-1}\right)$ was found in the headspace fraction, while 2-penten-1-ol, 3-hexenyl butanoate, octadecane and hexanoic acid $\left(<0.01 \mu \mathrm{g} . \mathrm{kg}^{-1}\right)$ were by far the less abundant volatile compounds. Both 2-penten-1-ol and 3-hexenyl butanoate were only tentatively identified in the headspace fraction. The first compound has been recently reported in Brazilian Cambará honey (MOREIRA; DE MARIA, 2005). The remaining volatile compounds $(83 \%)$ were considered definitively identified by comparison of retention times and mass spectral data with those of authentic reference compounds.

The headspace fraction exhibited a different qualitative and quantitative volatile pattern in comparison to that from "assa-peixe" honey aqueous extract (MATOS et al., 2002), where a predominance of medium- and high-boiling-point volatile compounds was observed. On the other hand, tetradecane, 2-ethyl-1-hexanol, pentadecane, hexadecane, 3-hexenyl butanoate, octadecane and hexanoic acid were found in both aroma concentrates.

A review of the literature revealed that benzaldehyde, the second most abundant volatile component of the "assa-peixe" honey headspace fraction, was also a major volatile compound in the headspace fraction of Brazilian "cambará" (Gochnatia velutina) honey (37 $\mu \mathrm{g} \mathrm{kg}^{-1}$ ) (MOREIRA; DE MARIA, 2005). Furthermore, benzaldehyde has already been identified in haze (Rhus succedanea) honey from Japan (SHIMODA; WU; OSAJIMA, 1996) and in lavender (Lavandula augustifolia) and eucalyptus (Eucalyptus sp.) (BOUSETA; SCHEIRMAN; COLLINS, 1996) honeys from different European countries.

\section{Conclusion}

Among the 12 volatile compounds found in the headspace fraction analysed in this study, 3-penten-2-one, dodecane, tridecane and benzaldehyde were definitively identified for the first time as "assa-peixe" honey constituents.

\section{Acknowledgments}

This work has been funded by the Fundação de Amparo à Pesquisa do Rio de Janeiro (FAPERJ) and Conselho Nacional de Desenvolvimento Científico e Tecnológico (CNPq). We thank Dr. Ortrud M. Barth for the floral type analysis.

\section{References}

BOUSETA, A.; SCHEIRMAN, V.; COLLINS, S. Flavor and free amino acids composition of lavender and eucalyptus honey, J. Food Sci., USA, v. 61, n. 4, p. 683-687, 1996.

LOUVEAUX, J.; MAURIZIO, A.; WORWOHL, G.; Methods of melissopalynology, Bee World, USA, v. 59, n.4, p. 139-157, 1978. 
MATOS, L. M. C. et al. Aroma compounds in morrão de candeia (Croton sp.) and assa-peixe (Vernonia sp.) honeys, Ital. J. Food Sci., Italy, v. 14, n. 3, p. 267-278, 2002.

MOREIRA, R. F. A.; DE MARIA, C. A. B. Investigation of the aroma compounds from headspace and aqueous solution from the cambará (Gochnatia velutina) honey, Flavour Fragr. J., USA, v. 20, n. 1, p. 13-17, 2005.
SHIMODA, M.; WU, Y.; OSAJIMA, Y. Aroma compounds from aqueous solution of haze (Rhus succedanea) honey determined by adsorptive column chromatography, J. Agric. Food Chem., USA, v. 40, n. 12, p. 3913-3918, 1996.

VAN DEN DOOL, H.; KRATZ, P. D. A generalization of the retention index system including linear temperature programmed gas-liquid partition chromatography, J. Chromatogr., USA, v. 11, p. 463-471, 1963. 